ERRATUM OPEN

\title{
Erratum: Combinatorial treatment with natural compounds in prostate cancer inhibits prostate tumor growth and leads to key modulations of cancer cell metabolism
}

Alessia Lodi ${ }^{1}$, Achinto Saha ${ }^{2}$, Xiyuan Lu ${ }^{1}$, Bo Wang ${ }^{1}$, Enrique Sentandreu ${ }^{1}$, Meghan Collins ${ }^{1}$, Mikhail G. Kolonin ${ }^{4}$, John DiGiovanni ${ }^{2,3}$ and Stefano Tiziani $\mathbb{B D}^{1,3}$

npj Precision Oncology (2017)1:30; doi:10.1038/s41698-017-0027-9

Erratum to: npj Precision Oncology (2017); doi:10.1038/s41698017-0024-z; Published 05 June 2017

The supplemental tables were missing in the original publication. These files have now been added in the HTML of this Article.

Open Access This article is licensed under a Creative Commons Attribution 4.0 International License, which permits use, sharing, adaptation, distribution and reproduction in any medium or format, as long as you give appropriate credit to the original author(s) and the source, provide a link to the Creative Commons license, and indicate if changes were made. The images or other third party material in this article are included in the article's Creative Commons license, unless indicated otherwise in a credit line to the material. If material is not included in the article's Creative Commons license and your intended use is not permitted by statutory regulation or exceeds the permitted use, you will need to obtain permission directly from the copyright holder. To view a copy of this license, visit http://creativecommons. org/licenses/by/4.0/.

(c) The Author(s) 2017

\footnotetext{
${ }^{1}$ Department of Nutritional Sciences, The University of Texas at Austin, Austin, TX, USA; ${ }^{2}$ Division of Pharmacology and Toxicology, College of Pharmacy, The University of Texas at Austin, Austin, TX, USA; ${ }^{3}$ Dell Pediatric Research Institute, The University of Texas at Austin, Austin, TX, USA and ${ }^{4}$ The Brown Foundation Institute of Molecular Medicine, University of Texas Health Science Center at Houston, Houston, TX, USA

Correspondence: Stefano Tiziani (tiziani@austin.utexas.edu)

Alessia Lodi and Achinto Saha contributed equally to this work.
} 